\title{
Moda Tasarımı Öğrencilerinin Giyim Markalarına Yönelik Görüssleri: Giresun Üniversitesi Örneği
}

\author{
DOI: $10.26466 /$ opus.521104 \\ *
}

Tuğba Seferoğlu* - Hatice Harmankaya*

* Öğr. Gör. Giresun Üni. Şebinkarahisar Uyg. Bilimler Y.O., Şebinkarahisar/Giresun/Türkiye E-Posta: tugba.yildiz@giresun.edu.tr ORCID: 0000-0002-2366-4278

** Doç. Dr. Selçuk Üniversitesi, Sanat ve Tasarım Fakültesi, Selçuklu / Konya / Türkiye E-Posta: harmankayahatice@selcuk.edu.tr ＯRCID: 0000-0001-6375-7586

Öz

Bu çalışmanın amacı, giyim markalarına ait özelliklerin moda tasarımı öğrencileri tarafından algılanma durumların belirlemektir. Betimsel araştırma yönteminin kullanıldı̆̆ ç̧alışmanın örneklemi Giresun Üniversitesi Şebinkarahisar Uygulamah Bilimler Yüksekokulu Moda Tasarımı Bölümü öğrencilerinden oluşmaktadır. Veriler geliştirilen anket formu ile elde edilmiştir. Anket, öğrencilerin demografik özellikleri, giyim alışverişinde önem verdikleri özellikler, giyim markalarından beklentileri ve giyim markalarına yönelik görüşleri olmak üzere dört ana bölümden oluşmaktadır. Katılımciların giysi alışverişinde önem verdikleri özelliklerini ve giysi markalarından beklentilerini ölçmek amacıyla 5'li likert tipi ölçek kullanılmıştır. Araştırmada marka özellikleri duygusal faktörler, marka kişiliği, fiziksel faktörler olmak üzere ̧̈̈̈ değişken başlı̆̆ı altında yapılandırılarak üniversite öğrencilerinin araştırma kapsamındaki markalara ait görüşleri belirlenmiştir. Elde edilen bulgular tablolarda yüzde ve sayı değerleri olarak verilmiştir. Bununla birlikte üniversite öğrencilerinin moda markaların algılanmalarında dikkat ettikleri özellikler ve lisans düzeyleri arasında da istatistiksel ilişkinin ölçümü için $\chi^{2}$ ilişki analizi kullanılmıştır. Araştırma grubunda yer alan katılımcıların lisans düzeylerine göre giysi alışverişinde önem verdikleri özellikler ve giyim markalarından beklentiler arasında istatistiksel olarak anlamlı bir fark olup olmadığını test etmek için ise verilere ANOVA analizi yapılmıştır. Çalışma sonucunda, işletmeler açısından marka imajı ve marka kişiliği oluşturmanın tüketici üzerinde belirleyici bir etkisi olduğu ve markanın soyut olarak nitelendirilen özelliklerinin genç tüketici kitlesi tarafindan net bir biçimde anlaşıldı ̆̆ belirlenmiştir.

Anahtar Kelimeler: Moda, Marka Algısl, Giyim, Üniversite Öğrencileri. 


\title{
Fashion Design Students' Views on Clothing Brands: Giresun University Study Case
}

\begin{abstract}
The aim of this study is to determine the perception status of the cloth brands characteristics by fashion design students. The sample of the study using descriptive research method consists of the students in Giresun University, Şebinkarahisar School of Applied Sciences, Fashion Design Department. The data were obtained with the developed questionnaire. The questionnaire consists of four main sections: demographic characteristics of the students, features that students care about clothes exchange, students ' expectations from cloth brands and finally their opinions about cloth brands. The five - likert type scale was used in order to measure the characteristics participants care about clothes exchange and the participants' expectations from the cloth brands. In this research, university students' opinions on the brands covered by the research were determined by structuring 'Brand Features' under three variables including emotional factors, brand personality and physical factors. The results obtained from this research were given as percentage and number values in the tables. In addition, $\chi^{2}$ correlation analysis was used to measure the statistical relationship between characteristics university students pay attention in the fashion brands perceptions and their license levels. Furthermore, ANOVA analysis was performed in order to test whether there is a statistically significant difference between characteristics participants in the research group care about according to their license level on clothes exchange and their expectation from cloth brands. As a result of the study, it has been revealed that creating brand image and brand personality for the enterprises has a decisive effect on the consumer. It is determined that the brand's abstract features are clearly understood by the young consumer population.
\end{abstract}

Keywords: Fashion, Brand Perception, Clothing, University Students. 


\section{Giriş}

Marka, bireyin satın aldığı üründen elde ettiği tatmini oluşturan özelliklerin tamamıdır. Bu özellikler, markayı oluşturan gerçek ya da hayali, rasyonel ya da duygusal, görünür ya da görünmez gibi markayı oluşturan unsurlardır (Sevil, 2006, s.66). Üretilen bir malın imajı, müşteri memnuniyeti, reklam, rekabet gibi çeşitli faktörlere bağlı olmakla birlikte bu konuda yapılan her türlü çaba tüketici gözünde marka adı altında toplanmaktadır (Işık, 2007, s.17). Birçok firma tarafından üretilen ürünleri veya sunulan hizmetleri birbirinden ayırt etmek, tanımlamak, ürün veya hizmet hakkında bilgi vermek, bir imaj yaratmak, kimlik kazandırmak için bu ürün ve hizmetleri tanıtan sembol, dizayn, renk, ambalaj, etiket, tasarım ve bu unsurların bütünü 'marka' olarak karşımıza çıkmaktadır (Bağrışen, 1999, s.371). Dolayısıyla ürünlerde farklılık yaratmak ve tüketicilerin dikkatini çekmek amacıyla markanın sembolik özelliklerine vurgu yapılması kaçınılmaz hale gelmiştir (Odabaşı, 2006, s.95). Bununla birlikte marka, tüketicilerin satın alma davranışlarını etkileyen bir faktör konumundadır. Ancak bu, olumlu bir faktör olabileceği gibi olumsuz bir faktör de olabilir (Yousaf vd. 2012, s. 327). Bu durumda olumsuz faktörlerin ortadan kaldırılması, tüketicilerin markaya duyduğu güvenin ve bağlılığın artırılmasıyla sağlanmaktadır. Aynı zamanda marka, tüketici belirsizliğini azaltmak ve böylece ürünlerin satın alınmasını teşvik etmek amacıyla pazarlama yöneticileri için de bir anahtar görevi üstlenmektedir (Song vd., 2012, s.332).

Marka bir ürün veya hizmetten farklı olarak sadece ticari bir anlam, kayg1 gütmez. Marka bir duygu işidir. Bu yüzden marka kavramı; duygu ve alg1 kavramları ile paralel olacak şekilde birbirlerinden beslenerek tanımlanabilmektedir (Kaptanoğlu vd., 2019, s.248).

Marka değer sistemlerinin; kişilik, imaj, logo, risk azaltıcı faktörler, şirket katma değerleri, vizyon ve konumlandırma gibi birçok farklı bileşeni içerdiği tespit edilmiştir. Bu bakış açısıyla, bir markanın üründen daha kapsamlı anlamlar içerdiği görülür. Her marka bir üründür ama her ürün bir marka değildir. Ürün, üretim süreci sonrasında ortaya çıkan bir nesne, marka ise tüketiciler tarafından satın alınan değerdir (Karataş ve Altunışık, 2015, s.138). Marka ile ürün arasındaki bu önemli fark ürünün nesne veya hizmet olması, markanın ise tüketici tarafından algılanan bir sembol 
veya işaret olmasıdır. Ürünün farklı boyutları, biçimleri ve özellikleri vardır. Ürün, zaman içinde değişebilir veya geliştirilebilir. Tüketiciye fiziksel fayda sağlar. Somuttur ve fiziksel bileşenleri vardır. Marka ise yaratıcllığa dayanan kavramdır. Tüketici ihtiyaçlarının giderilmesinde tatmin edicidir ve kalıcılığı sağlar. Tüketici tarafından statü göstergesi olarak algılanır, kişiliği vardır. Marka, ürünün aksine, soyuttur ve duygusal bileşenleri mevcuttur. Ürün beynin sol tarafına (rasyonel) yönelik iken, marka beynin sağ tarafına (duygusal) yönelik çalışır (Kırdar, 2005, s. 234). Tüketiciler bir ürünü satın alırken ürünün ihtiyaçalarını karşılayabilme kabiliyetini ve ekonomik anlamda ederini yani fiyatı, ambalajı, kalitesi, garantisi veya satış sonrası hizmetlerini dikkate alırlar. Bunula birlikte markaya ait özelliklerin tüketiciler tarafından algılanma şekli yani marka kimliği de tüketicilerin satın alma kararlarında önemli bir etkendir (Sönmez, 2010, s.68). Tüketicilerin satın alma kararlarını etkileyen ve işletmelerin sundukları benzer ürünleri birbirlerinden ayıran marka, pazarlama ve reklam faaliyetlerinin odak noktasıdır. Günümüzde aynı amaçlar için üretilen ürünler arasında farklılıklar kalmamıştır. İşletmeler için önemli olan hedef kitlelerinin kendilerini nasıl algıladıkları, ürün ve markalarına karşı nasıl bir tutum ve davranış içinde oldukları ve markadan beklentileridir.

Günümüzde özellikle giyim sektöründe artan rekabet ortamının da etkisi ile işletmeler varlıklarını sürdürebilmek ve ayakta kalabilmek için ciddi bir mücadele içindedirler. Küreselleşmenin etkisi, teknoloji alanındaki hızlı gelişmeler, toplum yapısında meydana gelen değişiklikler ve gelişmeler ile birlikte işletmeler için üretim yapmak sorun olmaktan çımış, bunun yerine ürünlerinin pazarlamasını yapmak daha büyük bir sorun haline gelmiştir (Denli, 2007, s.5). Bir mal veya hizmetin planlanmasında ve daha da önemlisi alıcı bulmasında en önemli unsur ürünün markasıdır. Tüketicinin kalite, özgünlük, kontrolü yapmaya gerek duymaksızın belli bir markaya duyduğu güven, hatta marka kültürünün iyice gerçekleştiği günümüzde belli markalarda ürünlere sahip olma ya da hizmetlere başvurmanın sosyal çevrelerde kazandırdığı saygınlık, söz konusu mal veya hizmeti tercih etmesinin tek nedeni olabilmektedir (Atl1, 2001, s.62). Marka ürün çeşitliliğinin çok fazla olduğu giyim sektöründeki tüketici tercihlerinde önemli bir unsurdur. Tüketicilerin çoğu giysi satın alma kararını verirken farklı oranlarda markanın etkisi altında kalmaktadır. 
Vazgeçilmez bir tüketim alanı olan giyim sektöründe tüketiciler, çok sayıdaki ürün arasından seçim yaparken kendisiyle bağlantı kurabildiği, düşüncelerine ve duygularına rehber olan markalara yönelmektedir (Azizağaoğlu ve Altunışık, 2011, s.41). Tüketiciler için marka, belirli bir bedel karşılığında sahip olacağı bir ürünü tanımanın en kolay yoludur. Ürün haklarında müşteriyi bilgilendirir, bir ürünün kolayca hatırlanmasını ve satın alınmasını sağlar (Eray, 1999, s.103).

Markalar bağlı olduğu firmayı temsil ederler. Marka sadece isim ve simge olmanın ötesinde firma ve ürün hakkında tüketicinin taşıdığ duygu ve düşüncelerin ifade etme şeklidir. Markaya yönelik tutumlar, marka kalitesine duyulan güven ve sunulan hizmetler sonucunda tüketicilerin zihninde yavaş yavaş marka algısı oluşturmaktadır. Ürünler tüketicilerin fiziksel ve estetik anlamda ihtiyaçlarını karşılayabilme kabiliyetlerine göre sınıflandırılırken, markalar tüketicinin nesnel anlamdaki ihtiyaçlarının yanı sıra psikolojik ve sosyal ihtiyaçlarını karşılayabilme becerisi sağlar. Reklamlarında veya alışveriş sırasında kaynaktan gönderilen marka adı, reklam, görsel her türlü simge ve mesajlar tüketicinin marka imajını biçimlendirmesi açısından önemlidir. Özelikle bilişim çağının baskın olarak yaşandığı teknolojik bir ortamda markalar, ürünlerine işletmelerine, değerlerine yönelik aktarmak istedikleri mesajları tüketicilerine kolayca ulaştırabilmekte ve tüketicilerinden hızlı dönüt alabilmektedirler. Tüketici ihtiyaçları doğrultusunda satın alma kararı öncesinde, satın alma esnasında ve sonrasında tüketicilerin hangi aşamalardan geçtiklerini, hangi etmenlerden etkilendiklerini ve kararlarının nelere göre şekillendirdiklerini belirlemek önemlidir.

Ürünler, kimliğe bağlı olarak marka yönetiminin belirlediği özellik ve niteliklere göre farklı düzeylerdeki kimliklerle üretilmektedirler. Marka birden farklı kimlikten oluşmaktadır. Öz kimlik markanın mevcuttaki ürünleri dışında yeni pazarlar ve yeni ürünlerde sabit kalmasıdır. Genişletilmiş kimlik ise birbibirne bağlı ilerleyen markaya özel diğer unsurlardır (Aaker, 1997, s.84). Markaların farklılık yaratmakta kullandıkları stratejilerden bir diğeri de müşterinin zihninde markanın kimliğine uyacak bir kişilik oluşturmaktır. Marka kişiliği ile fiziksel özellikli ürüne, sembolik değerler yüklemektedir. Hazırlanan tüm reklamlarda marka kimliği, ürün üzerinden müşterinin kullanımına sunulmakta ve müşterilerin bunu deneyimlemesi beklenmektedir. Ürünün müşteride bıraktığ 1 çağrışımlara 
bağlı alınan dönütlere göre marka kişiliği geliştirilmektedir. Aaker marka kişiliğini, insanların kişilik özelliklerine göre "samimi, heyecanlı, yetenekli, entelektüel ve dayanıklı" şeklinde beş temel altında toplamıştır (Çeğindir ve Çakmak, 2018, s.38). Çağdaş toplumlarda, insanlar kimliklerini geliştirmekle sürekli olarak meşguller; Bu nedenle, ürünlerin sembolik nitelikleri genellikle satın alımlarının temel nedenleridir. Marka kişiliği veya "bir markayla ilişkili insan özellikleri kümesi" tüketicinin ilgisini çeken ve satın alma kararlarını etkileyen sembolik ve duygusal anlamlara işaret eder (Su ve Tong, 2019, s.427). Samimiyetin temsili olarak kullanilan yumuşak organik hatlar, çizgiler, desenler ve formlar, ürünün samimiyetle konumlanan marka kişiliği ile bağdaşmasına yardımcı olabilir. Geometrik çizgileri taşıyan formlar, desenler daha dayanıklılığa ve entelektüelliğe vurgu yapabilir. Ürün tasarımı ve kullanımında seçilen renkler ve desenler, form ve deteaylar müşteriler üzerinde marka kişiliği oluşturulmasında, istenen algıyı yaratabilir (Çeğindir ve Çakmak, 2018, s.39). Aaker (1997) tarafından tanımlanan kişilik özellikleri zamanla, farklı araştırmacıların literatüre kazandırdığı yeni kişiliklerle zenginleştirilmiştir. Bu zenginlik sayesinde, yirminci yüzyılın başındaki nesnenin hacimsel üretimine dayanan satış odaklı ürün geliştirme faaliyetlerinin yerini yirmi birinci yüzyılda, müşterinin fiziksel, ekonomik, sosyal ihtiyaçlarının tatmininin daha üstündeki duyusal tatmine yönelik kişiliklerin ürüne aktarılması faaliyetleri almıştır. Bugünün ürün yönetiminin başarısı, marka ve ürün kişiliğinin kullanıcı kişiliği ile özdeşleşmesine hedeflenmektedir.bu hedeflere bağlı olarak, marka kişiliğindeki yeni yöntemlerin, ürün ve ürün geliştirme faaliyetlerini doğrudan etkilediği söylenebilir (Çeğindir ve Çakmak, 2018, s.40).

$\mathrm{Bu}$ araştırmada üniversite öğrencilerinin giysi alışverişlerinde önem verdikleri özellikleri, giysi markalarından beklentilerini, markalara yönelik tutumlarını ve marka bağlılıkları olup olmadığını ortaya koymak çalışmanın temel amacını oluşturmaktadır. Bununla birlikte üniversite öğrencilerinin demografik özelliklere göre markaya bağlılığının farklılaşıp farklılaşmadığını belirlemek de alt amaçlar arasında yer almaktadır. 


\section{Yöntem}

Araştırmanın materyalini Giresun Üniversitesi Şebinkarahisar Uygulamalı Bilimler Yüksekokulu Moda Tasarımı Bölümü 1. 2. 3. ve 4. Sınıf öğrencilerinden anket yardımı ile elde edilen veriler ve ilgili kaynaklar oluşturmaktadır. Araştırmada giyim marklarının üniversite öğrencileri tarafından algılanma durumlarının belirlenmesi amaçlandığından betimsel (survey) yöntem uygulanmıştır. Bu araştırmanın evrenini Giresun Üniversitesi Şebinkarahisar Yerleşkesi öğrencileri; örneklemi ise Moda Tasarımı Bölümü öğrencileri oluşturmaktadır. Hazırlanan anket, her sınıf derecesinden 38 kişi olacak şekilde 152 kişiye uygulanmış ve bunlardan 138 'i analizler için uygun bulunmuştur. Anket, öğrencilerin demografik özellikleri, giyim alışverişinde önem verdikleri özellikler, giyim markalarından beklentileri ve giyim markalarına yönelik görüşleri olmak üzere dört ana bölüm olmak üzere 11 sorudan oluşmaktadır. Katılımcıların giysi alışverişinde önem verdikleri özelliklerini ve giysi markalarından beklentilerini ölçmek amacıyla 5'li likert tipi ölçek kullanılmıştır. Araştırmada marka özellikleri; duygusal faktörler, marka kişiliği, fiziksel faktörler olmak üzere üç değişken başlığı altında yapılandırılarak üniversite öğrencilerinin araştırma kapsamındaki markalara ait görüşleri belirlenmiştir. Ankette, hızlı modaya hitap eden yerli A markası, hızlı modaya hitap eden yabancı B markası, üst düzey gelir düzeyine sahip tüketici kitlesine hitap eden yerli $C$ markası, alım gücü yüksek müşteri kitlesine sahip yabancı D markası, rahat giyim açısından ise dünyaca tanınan yerli $\mathrm{E}$ ve yine spor giyimde öncü tanınırlığı yüksek yabancı F markaları seçilmiştir. Marka seçimlerinde tüketiciler tarafından genel anlamda en bilinenlere yer verilmiştir. Anket güvenilirliği ölçülmüss ve Cronbach Alpha $(\alpha) \% 95.2$ bulunmuştur. Araştırma sürecinde veri toplama işlemi tamamlandıktan sonra ankete verilen cevaplar kontrol edilmiş, eksik ya da hatalı anketler ayrılmış ve doğru olan anketler üzerinde istatistiksel analizler yapılmak üzere veriler SPSS paket programına aktarılmıştır. Elde edilen bulgular tablolarda yüzde ve sayı değerleri olarak verilmiştir. Bununla birlikte üniversite öğrencilerinin moda markalarını algılanmalarında dikkat ettikleri özellikler ve lisans düzeyleri arasında da istatistiksel ilişkinin ölçümü için $\chi^{2}$ 
ilişki analizi kullanılmıştır. Araştırma grubunda yer alan katılımcıların lisans düzeylerine göre giysi alışverişinde önem verdikleri özellikler ve giyim markalarından beklentiler arasında istatistiksel olarak anlamlı bir fark olup olmadığını test etmek için ise verilere ANOVA analizi yapılmıştır. Verilerin istatistiksel analizinde ve yorumlarda, $\alpha=0.05$ anlamlılık düzeyi dikkate alınmıştır. Çalışmada markalar duygusal faktörler, marka kişiliği, fiziksel özellikler bakımından incelenirken çeşitli kaynaklardan yararlanılmıştır (Aktuğlu ve Temel, 2006; Özçelik ve Torlak, 2011; Çetin, 2016; Ağaç ve Sevinir, 2017; Çeğindir ve Çakmak, 2018; Kaptanoğlu vd., 2019; Erdem vd., 2010). Araştırmalar dikkate alınarak anket bölümleri ve seçenekler araştırmacılar tarafından oluşturulmuştur.

\section{Bulgular}

Araştırma kapsamında, üniversite öğrencilerinin giysi markalarını algılama durumlarını belirlemek amacı ile frekans ve yüzde değerleri hesaplanmış ve bulgular tablolarda verilmiştir. Araştırma kapsamındaki öğrenci ebeveynlerinin eğitim durumu incelendiğinde en fazla yı̆̆ılmayla anne (\%63.8) ve babanın (\%42) ilkokul mezunu olduğu belirlenmiştir. Katılımcıların aylık eline geçen para miktarı en fazla yığılmayla $500 \mathrm{TL}$ ve üzeri (\%43.5) ve 400-500 TL (\%21.7) arasındadır. Giyim alışverişine harcanan aylık ortalama miktarın ise en fazla 50-100 TL aralığında (\%54.3) olduğu ortaya çıkmıştır. Katılımcıların eline geçen aylık para miktarı 500 TL ve üzeri olmasına rağmen giyim harcamalarına 50 ile $100 \mathrm{TL}$ arasında harcama yapılması, $200 \mathrm{TL}$ ve üzeri (\%5.1) neredeyse hiç giyim harcaması yapılmaması dikkat çekicidir. Öğrencilerin aileleri ile birlikte yaşadığ şehirlere bölge bazında bakıldığında en fazla yığılmayla Marmara (\%39.8) ve Karadeniz Bölgesindeki (\%28.1) şehirlerden geldikleri görülmüştür.

Tablo 1. Üniversite Öğrencilerinin Giysi Alışverişi Yapma Sıklı̆̆ı

\begin{tabular}{lll}
\hline Seçenekler & s & \% \\
\hline Bütçesi Olduğu Zaman & 57 & 41.3 \\
\hline Kendine Uygun Bir Model Bulduğunda & 42 & 30.4 \\
\hline İhtiyacı Olduğu Zaman & 36 & 26.1 \\
\hline Sezon Sonunda & 5 & 3.6 \\
\hline Sezon Başında & - & - \\
\hline Özel Günlerde & 2 & 1.4 \\
\hline
\end{tabular}


Üniversite öğrencilerinin alışveriş yapma sıklığına ilişkin bulguların yer aldığ 1 Tablo 1 incelendiğinde, üniversite öğrencilerinin en fazla bütçesi uygun olduğu zaman (\%41.3), kendine uygun bir model bulduğunda (\%30.4) ve ihtiyacı olduğu zaman (\%26.1) alışveriş yaptıkları görülür. Öğrencilerin sezon başında hiç alışveriş yapmadıkları belirlenmiştir. Bulgulara göre, özellikle özel günlerde de alışveriş yapılmaması oldukça dikkat çekicidir. Öğrencilerin giysi alışverişi yapma sıklıkları konusunda yapılan $\mathrm{x}^{2}$ analizi sonucunda, ihtiyacım olduğu zaman (0.037) seçeneği ile sınıf düzeyleri arasında anlamlı bir ilişki bulunmuştur.

Tablo 2. Üniversite Öğrencilerinin Giysi Alışverişinde Önem Verdikleri Özellikler

\begin{tabular}{|c|c|c|c|c|c|c|c|c|c|c|}
\hline \multirow[t]{2}{*}{ Seçenekler } & \multicolumn{2}{|c|}{ 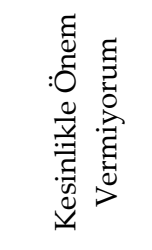 } & \multicolumn{2}{|c|}{ :0 } & \multicolumn{2}{|c|}{ 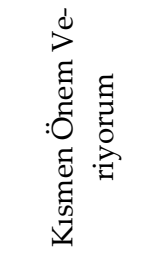 } & \multicolumn{2}{|c|}{ 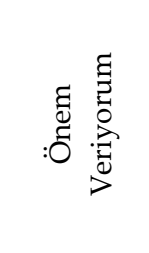 } & \multicolumn{2}{|c|}{ 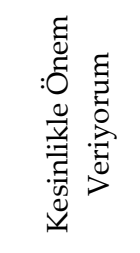 } \\
\hline & $\mathrm{s}$ & $\%$ & $\mathrm{~s}$ & $\%$ & $\mathrm{~s}$ & $\%$ & $\mathrm{~s}$ & $\%$ & $\mathrm{~s}$ & $\%$ \\
\hline $\begin{array}{l}\text { Kaliteli Ürünler Ol- } \\
\text { ması }\end{array}$ & 13 & 9.4 & 5 & 3.6 & 27 & 19.6 & 38 & 27.5 & 55 & 39.9 \\
\hline $\begin{array}{l}\text { Sicak ve Güvenilir } \\
\text { Bir Ortam }\end{array}$ & 13 & 9.4 & 6 & 4.3 & 33 & 23.9 & 49 & 35.5 & 37 & 26.8 \\
\hline $\begin{array}{l}\text { Bütçeme Uygun Bir } \\
\text { Alışveriş Olması }\end{array}$ & 10 & 7.2 & 8 & 5.8 & 12 & 8.7 & 41 & 29.7 & 67 & 48.6 \\
\hline $\begin{array}{l}\text { Satış Sonrası Güçlü } \\
\text { Destek }\end{array}$ & 7 & 5.1 & 14 & 10.1 & 41 & 29.7 & 45 & 32.6 & 31 & 22.5 \\
\hline $\begin{array}{l}\text { Satış Esnasında Bil- } \\
\text { gilendirilme }\end{array}$ & 15 & 10.9 & 9 & 6.5 & 30 & 21.7 & 43 & 31.2 & 41 & 29.7 \\
\hline Kolay Ulaşılabilirlik & 11 & 8 & 10 & 7.2 & 11 & 8 & 42 & 30.4 & 64 & 46.4 \\
\hline $\begin{array}{l}\text { İhtiyacımın Tama- } \\
\text { men Karşılanması }\end{array}$ & 15 & 10.9 & 2 & 1.4 & 10 & 7.2 & 32 & 23.2 & 79 & 57.2 \\
\hline $\begin{array}{l}\text { Psikolojik Tatmin } \\
\text { Sağlaması }\end{array}$ & 12 & 8.7 & 13 & 9.4 & 20 & 14.5 & 33 & 23.9 & 60 & 43.5 \\
\hline
\end{tabular}

Üniversite öğrencilerinin giysi alışverişinde önem verdikleri özelliklere ilişkin bulguların yer aldığı Tablo 2 incelendiğinde, katılımcıların \%57.2'sinin giysilerin ihtiyaçlarını tamamen karşılanmasına, \% 48.6'sının 
bütçeye uygun bir alışveriş olmasına, \%46.4'ünün giysilerin kolay ulaşılabilir olmasına, \%43.5'inin giysilerin psikolojik tatmin sağlamasına, \%39.9'unun kaliteli ürünler olmasına, \%29.7'sinin satış esnasında bilgilendirme olmasına kesinlikle önem verdikleri belirlenmiştir. Öğrencilerin \%35.5' inin sıcak ve güvenilir bir ortam, \%32.6'sının satış sonrası güçlü destek, \%31.2'sinin satış esnasında bilgilendirme olmasına, \%30.4'ünün kolay ulaşılabilirliğe, \%29.7 bütçeye uygun bir alışveriş olmasına, \%27.5'inin kaliteli ürünler olmasına önem verdikleri belirlenmiştir. Satış sonrası güçlü destek verilmesi (\%29.7), sıcak ve güvenilir bir ortam olması (\%23.9) aynı zamanda da k̂ımen önemli bulunmuştur.

Tablo 3. Öğrencilerin Sını Düzeyi ile Giysi Alışverişinde Önem Verdikleri Özellikler ANOVA Testi

\begin{tabular}{llllll}
\hline $\begin{array}{l}\text { Sinıf } \\
\text { Düzeyi }\end{array}$ & $\mathbf{N}$ & $\overline{\mathbf{x}}$ & Ss & $\mathbf{F}$ & $\mathbf{P}$ \\
\hline 1. Sinif & 23 & 3.85 & 3.85 & & \\
2. Sinıf & 22 & 3.47 & 3.47 & 3.488 & 0.018 \\
3. Sinif & 29 & 3.58 & 3.58 & & \\
4. Sinıf & 64 & 4.09 & 4.09 & & \\
\hline
\end{tabular}

Yapılan Anova testi sonucunda üniversite öğrencilerinin sinıf düzeyleri ile giysi alışverişinde önem verdiği özellikler arasında $\mathrm{p}<0.05$ olduğu için anlamlı bir ilişkinin olduğu belirlenmiştir.

Üniversite öğrencilerinin giyim markalarından beklentilerine ilişkin bulguların yer aldığı Tablo 4 incelenmiştir. Katılımcıların markalardan kalıplarının bedene uygun olmasını (\%68.1), model çeşitliliğinin fazla olmasin1 (\%63), ekonomik olmasını (\%55.8), farklı model özelliklerine sahip koleksiyonlarının olmasın (\%51.4), giysilerde dayanıklı malzeme ve materyaller kullanmasını (\%44.2), markaya ait sembol ve logonun giysinin üzerinde yer almasını (\%26.8) kesinlikle bekledikleri belirlenmiştir. Katılımclar, markanın kendine ait bilgilerini paylaşmasına (\%31.2), fonksiyonel özelliklere sahip olmasına (\%30.4), markaların dayanıklı malzeme ve materyaller kullanmasına (\%27.5) ve sosyal sorumluluk taşımalarına (\%27.5) katıldıklarını ifade etmişlerdir. Katılımcıların markanın fonksiyonel özelliklere sahip olmasına (\%32.6), markanın sosyal sorumluluk taşımasına (\%31.9), markaya ait sembol ve logonun giysinin üzerinde yer almasına 
(\%29), tüm giysi çeşitlerini ve aksesuarları aynı markadan temin edebilmesine (\%25.4), markanın kendine ait bilgilerini paylaşmasına (\%24.6), giysinin herkes tarafından satın alınamamasına (\%23.2) kısmen katıldıkları ortaya çımıştır.

\section{Tablo 4. Üniversite Öğrencilerinin Giyim Markalarından Beklentileri}

\begin{tabular}{|c|c|c|c|c|c|c|c|c|c|c|}
\hline \multirow[t]{2}{*}{ Seçenekler } & \multicolumn{2}{|c|}{ 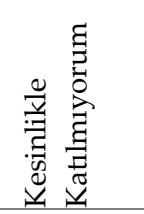 } & \multicolumn{2}{|c|}{ 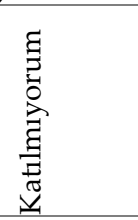 } & \multicolumn{2}{|c|}{ 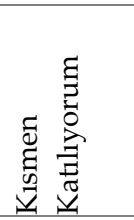 } & \multicolumn{2}{|l|}{ 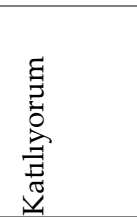 } & \multicolumn{2}{|c|}{ 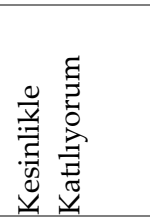 } \\
\hline & $\mathrm{s}$ & $\%$ & $\mathrm{~s}$ & $\%$ & $\mathrm{~s}$ & $\%$ & $\mathrm{~s}$ & $\%$ & $\mathrm{~s}$ & $\%$ \\
\hline Ekonomik Olmasını & 13 & 9.4 & 3 & 2.2 & 12 & 8.7 & 33 & 23.9 & 77 & 55.8 \\
\hline $\begin{array}{l}\text { Model Çeşitliliğinin } \\
\text { Fazla Olmasını }\end{array}$ & 14 & 10.1 & 2 & 1.4 & 5 & 3.6 & 30 & 21.7 & 87 & 63 \\
\hline $\begin{array}{l}\text { Kalıplarının Bedenime } \\
\text { Uygun Olmasını }\end{array}$ & 15 & 10.9 & 1 & 7 & 9 & 6.5 & 19 & 13.8 & 94 & 68.1 \\
\hline $\begin{array}{l}\text { Farklı Model Özellikle- } \\
\text { rine Sahip Koleksiyon- } \\
\text { ları Olması }\end{array}$ & 10 & 7.2 & 6 & 4.3 & 15 & 10.9 & 36 & 26.1 & 71 & 51.4 \\
\hline $\begin{array}{l}\text { Herkes Tarafından Satın } \\
\text { Alınamaması }\end{array}$ & 33 & 23.9 & 33 & 23.9 & 32 & 23.2 & 19 & 13.8 & 21 & 15.2 \\
\hline $\begin{array}{l}\text { Üst Düzey Ekonomik } \\
\text { Gelire Hitap Etmesi }\end{array}$ & 51 & 37 & 41 & 29.7 & 17 & 12.3 & 13 & 9.4 & 16 & 11.6 \\
\hline $\begin{array}{l}\text { Fonksiyonel Özelliklere } \\
\text { Sahip Olması }\end{array}$ & 9 & 6.5 & 18 & 13 & 45 & 32.6 & 42 & 30.4 & 24 & 17.4 \\
\hline $\begin{array}{l}\text { Dayanıklı Malzeme ve } \\
\text { Materyaller Kullanması }\end{array}$ & 12 & 8.7 & 3 & 2.2 & 24 & 17.4 & 38 & 27.5 & 61 & 44.2 \\
\hline $\begin{array}{l}\text { Sosyal Sorumluluk Taşı- } \\
\text { ması }\end{array}$ & 11 & 8 & 19 & 13.8 & 44 & 31.9 & 38 & 27.5 & 26 & 18.8 \\
\hline $\begin{array}{l}\text { Tüm Giysi Çeşitlerini ve } \\
\text { Aksesuarları Aynı Mar- } \\
\text { kadan Temin Edebilme }\end{array}$ & 16 & 11.6 & 38 & 27.5 & 35 & 25.4 & 22 & 15.9 & 27 & 19.6 \\
\hline $\begin{array}{l}\text { Markanın Kendine Ait } \\
\text { Bilgilerini Paylaşması }\end{array}$ & 8 & 5.8 & 24 & 17.4 & 34 & 24.6 & 43 & 31.2 & 29 & 21 \\
\hline $\begin{array}{l}\text { Markaya Ait Sembol ve } \\
\text { Logonun Giysinin Üze- } \\
\text { rinde Yer Alması }\end{array}$ & 14 & 10.1 & 26 & 18.8 & 40 & 29 & 21 & 15.2 & 37 & 26.8 \\
\hline
\end{tabular}


Markanın üst düzey ekonomik gelire hitap etmesine üniversite öğrencilerinin \%37'1 kesinlikle katılmamakta, \%29.7'si katılmamaktadır. Markanın herkes tarafından satın alınamamasına katılımcların \%23.9'u katılmamakta iken aynı oranla kesinlikle katılmaktadırlar. Üniversite öğrencilerinin üst düzey alım gücüne hitap eden markalar istememesi ve markanın herkes tarafından alınabilir olmasını olumlu karşılamaları markadan ekonomik olmasını beklemeleri ile tutarlı bir yaklaşım olmuştur.

Tüketiciler, çok sayıdaki ürün/marka arasından seçim yaparken kendisiyle arasında bağlantı kurabildiği ürünlere yönelmektedir. Bunun en önemli nedeni; teknolojik gelişmelerle ürünlerin/markaların fonksiyonel özellikleri bakımından birbirlerine giderek daha çok benzemeleri ve dolayısıyla ürünün/markanın fonksiyonel özelliklerinin ötesinde seçim kriterlerinin giderek daha belirleyici hale gelmeye başlamasıdır (Aaker, 2009, s. 224; Baudrillard, 2004, s. 18; Odabaşı, 2006, s. 94-96). Çünkü tüketiciler markaları, genellikle bir özelliği açısından değil, çeşitli özellikleri birleştirerek bir bütün içinde algılarlar (Aytuğ ve Özgüven, 2011, s. 83).

Tablo 5. Öğrencilerinin Sınıf Düzeyi ile Giyim Markalarından Beklentileri ANOVA Testi

\begin{tabular}{llllll}
\hline Sinıf Düzeyi & $\mathrm{N}$ & $\overline{\mathrm{X}}$ & Ss & $\mathrm{F}$ & $\mathrm{P}$ \\
\hline 1. Sinıf & 23 & 3.55 & 0.653 & & \\
2. Sinıf & 22 & 3.30 & 0.940 & 1.515 & 0.213 \\
3. Sinıf & 29 & 3.41 & 0.733 & & \\
4. Sinıf & 64 & 3.64 & 0.681 & & \\
\hline
\end{tabular}

Yapılan Anova testi sonucunda üniversite öğrencilerinin sınıf düzeyleri ile markalardan beklentileri arasında p>0.05 olduğu için anlamlı bir ilişkinin olmadığı belirlenmiştir.

Tablo 6' ya göre hızlı modada yerli A markasının_duygusal olarak: hesaplı aile odaklı (\%53.6), geleneksel (\%32.6), bağl1lık yaratan (\%24.6), marka kişiliği olarak: samimi (\%57.2), fiziksel özellikler açısından ise; her yaş grubuna uygun modeller bulunan (\%38.4), model çeşitliliği fazla (\%28.3), kalıpları bedene uygun (\%22.5) olduğu düşünülmektedir. 
Tablo 6. Üniversite Öğrencilerinin Giysi Markaları İle İlgili Görüşleri

\begin{tabular}{|c|c|c|c|c|c|c|c|c|c|c|c|c|c|}
\hline & \multirow{3}{*}{ Seçenekler } & \multicolumn{4}{|c|}{ Hızlı Moda Markalar } & \multicolumn{4}{|c|}{$\begin{array}{l}\text { Yüksek Gelir Düzeyine } \\
\text { Hitap Eden Markalar }\end{array}$} & \multicolumn{4}{|c|}{ Spor Markalar } \\
\hline & & \multicolumn{2}{|c|}{ A Yerli } & \multicolumn{2}{|c|}{$\begin{array}{c}\text { B } \\
\text { Yabanc1 }\end{array}$} & \multicolumn{2}{|c|}{ C Yerli } & \multicolumn{2}{|c|}{$\begin{array}{c}\text { D } \\
\text { Yabanc1 }\end{array}$} & \multicolumn{2}{|c|}{ E Yerli } & \multicolumn{2}{|c|}{$\begin{array}{c}\mathrm{F} \\
\text { Yabanc1 }\end{array}$} \\
\hline & & $\mathrm{s}$ & $\%$ & $\mathrm{~s}$ & $\%$ & $\mathrm{~s}$ & $\%$ & s & $\%$ & $\mathrm{~s}$ & $\%$ & $\mathrm{~s}$ & $\%$ \\
\hline \multirow{7}{*}{ 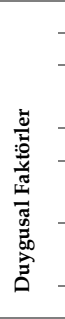 } & Bağlılık Yaratan & 34 & 24.6 & 30 & 21.7 & 27 & 19.6 & 40 & 29 & 45 & 32.6 & 43 & 31.2 \\
\hline & Yaraticı & 11 & 8 & 41 & 29.7 & 32 & 23.2 & 30 & 21.7 & 37 & 26.8 & 28 & 20.3 \\
\hline & $\begin{array}{l}\text { Farklılıklara } \\
\text { Hitap Eden }\end{array}$ & 12 & 8.7 & 29 & 21 & 26 & 18.8 & 22 & 15.9 & 29 & 21 & 22 & 15.9 \\
\hline & Geleneksel & 45 & 32.6 & 18 & 13 & 17 & 12.3 & 24 & 17.4 & 16 & 11.6 & 13 & 9.4 \\
\hline & $\begin{array}{l}\text { Hesaplı Aile } \\
\text { Odaklı }\end{array}$ & 74 & 53.6 & 5 & 3.6 & 9 & 6.5 & 11 & 8 & 17 & 12.3 & 6 & 4.3 \\
\hline & $\begin{array}{l}\text { Merak } \\
\text { Uyandıran }\end{array}$ & 4 & 2.9 & 25 & 18.1 & 21 & 15.2 & 18 & 13 & 24 & 17.4 & 20 & 14.5 \\
\hline & Dikkat Çeken & 6 & 4.3 & 34 & 24.6 & 39 & 28.3 & 31 & 22.5 & 37 & 26.8 & 38 & 27.5 \\
\hline \multirow{5}{*}{ 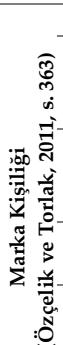 } & Samimiyet & 79 & 57.2 & 26 & 18.8 & 17 & 12.3 & 23 & 16.7 & 28 & 20.3 & 25 & 18.1 \\
\hline & $\begin{array}{l}\text { Coşku (Cesur, } \\
\text { Heyecanlı, } \\
\text { Kışkırtıcı) }\end{array}$ & 15 & 10.9 & 22 & 15.9 & 18 & 13 & 23 & 16.7 & 29 & 21 & 33 & 23.9 \\
\hline & $\begin{array}{l}\text { Ustalık (Güve- } \\
\text { nilir, Zeki, } \\
\text { Başarılı) }\end{array}$ & 14 & 10.1 & 31 & 22.5 & 26 & 18.8 & 31 & 22.5 & 32 & 23.2 & 37 & 26.8 \\
\hline & $\begin{array}{l}\text { Seçkinlik (Üst } \\
\text { sinıf, Cazip) }\end{array}$ & 13 & 9.4 & 51 & 37 & 40 & 29 & 44 & 31.9 & 33 & 23.9 & 35 & 25.4 \\
\hline & $\begin{array}{l}\text { Sertlik (Dışsal, } \\
\text { Sert) }\end{array}$ & 7 & 5.1 & 21 & 15.2 & 14 & 10.1 & 21 & 15.2 & 22 & 15.9 & 24 & 17.4 \\
\hline \multirow{7}{*}{ 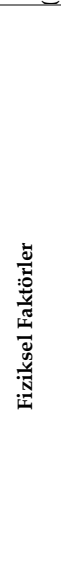 } & $\begin{array}{l}\text { Model Çeşitliliği } \\
\text { Fazla }\end{array}$ & 39 & 28.3 & 31 & 22.5 & 18 & 13 & 23 & 16.7 & 30 & 21.7 & 29 & 21 \\
\hline & $\begin{array}{l}\text { Modelleri } \\
\text { Özgün ve Ori- } \\
\text { jinal }\end{array}$ & 11 & 8 & 35 & 25.4 & 33 & 23.9 & 28 & 20.3 & 33 & 23.9 & 51 & 37 \\
\hline & $\begin{array}{l}\text { Kalipları Bedene } \\
\text { Uygun }\end{array}$ & 31 & 22.5 & 23 & 16.7 & 26 & 18.8 & 27 & 19.6 & 25 & 18.1 & 17 & 12.3 \\
\hline & $\begin{array}{l}\text { Modelleri Aks- } \\
\text { esuarlarla } \\
\text { Destekli }\end{array}$ & 17 & 12.3 & 16 & 11.6 & 13 & 9.4 & 18 & 13 & 10 & 7.2 & 6 & 4.3 \\
\hline & $\begin{array}{l}\text { Her Yaş Grub- } \\
\text { una Uygun } \\
\text { Modeller } \\
\text { Bulunan }\end{array}$ & 53 & 38.4 & 25 & 18.1 & 24 & 17.4 & 23 & 16.7 & 16 & 11.6 & 28 & 20.3 \\
\hline & $\begin{array}{l}\text { Modelleri Er- } \\
\text { gonomik }\end{array}$ & 15 & 10.9 & 20 & 14.5 & 10 & 7.2 & 23 & 16.7 & 22 & 15.9 & 26 & 18.8 \\
\hline & $\begin{array}{l}\text { Kumaşları } \\
\text { Doğaya Uygun }\end{array}$ & 13 & 9.4 & 13 & 9.4 & 21 & 15.2 & 18 & 13 & 14 & 10.1 & 14 & 10.1 \\
\hline
\end{tabular}

Hızlı modada öncü yabancı B markası, üniversite öğrencileri tarafından duygusal açıdan; yaratıcı (\%29.7), dikkat çeken (\%24.6), bağlllık yaratan (\%21.7), farklılıklara hitap eden (\%21), marka kişiliği olarak; seçkin (\%37), ustalık algısı uyandıran (\%22.5), fiziksel faktörler açısından; mod- 
elleri özgün (\%25.4) ve model çeşitliliği fazla (\%22.5) marka olarak bulunmuştur. Alım gücü yüksek müşteri kesimine sahip yerli C markası, duygusal açıdan; dikkat çeken (\%28.3), yaratıcı (\%23.2), marka kişiliği olarak; seçkin (\%29), fiziksel faktörler açısından; modelleri özgün ve orijinal (\%23.9) marka olarak ifade edilmiştir. Yüksek gelir düzeyine hitap eden yabancı D markası ise duygusal açıdan; bağlılık yaratan (\%29), dikkat çeken (\%22.5), yaratıcı (\%21.7), marka kişiliği olarak; seçkin (\%31.9), ustalık algısı uyandıran (\%22.5), fiziksel faktörler açısından; modelleri özgün ve orijinal (\%20.3), marka olarak kabul edilmektedir.

Rahat giyim tarzına hitap eden yerli E markası duygusal açıdan; bağlılık yaratan (\%32.6), aynı oranlarla yaratıcı ve dikkat çekici (\%26.8), farklılıklara hitap eden (\%21), marka kişiliği olarak; seçkin (\%23.9), ustalık alg1sı uyandıran (\%23.2), coşkulu (\%21), samimi (\%20.3), fiziksel faktörler açısından; modelleri özgün (\%23.9) ve model çeşitliliği fazla (\%21.7) marka olarak belirlenmiştir. Dünyaca ünlü spor giyim markası $\mathrm{F}$ için ise katılımclar duygusal olarak; bağlılık yaratan (\%31.2) ve dikkat çeken (\%27.5), duygusal olarak; ustalık algısı uyandıran (\%26.8), seçkin (\%25.4) ve coşkulu (\%23.9) fiziksel özellikler olarak; modelleri özgün ve orijinal (\%37) marka olduğunu belirtmişlerdir.

Öğrencilerin giysi markalarına yönelik görüşleri konusunda yapılan $\mathrm{x}^{2}$ analizi sonucunda, A markası; yaratıcı (0.044), seçkin (0.002), model çeşitliliğinin fazla olması (0.004), modellerin özgün ve orijinal olması (0.031), C markası; modellerin ergonomik olması (0.010), D markas1; modellerinin aksesuarla desteklenmesi (0.031), F markası; sertlik (0.035), her yaş grubuna uygun modellerinin olması (0.003), seçenekleri ile sınıf düzeyleri arasında anlamlı bir ilişki bulunmuştur.

\section{Sonuçlar}

Moda Tasarımı Bölümü'nde okuyan öğrencilerin markaların duygusal, marka kişiliği ve fiziksel faktörlerine ilişkin görüşlerini belirlemeye yönelik yapılan araştırma sonuçlarına göre; öğrenci ebeveynlerinin yüksek oranda ilkokul mezunu olduğu, öğrencilerin ellerine aylık 500 TL ve üzerinde para geçtiği, giyim alışverişine ise aylık 50 ile 100 TL harcadıkları ortaya çıkmıştır. Üniversite öğrencilerinin en fazla Marmara ve Karadeniz Bölgesinde aileleri ile birlikte yaşadıkları görülür. Moda 
Tasarımı öğrencilerinin en fazla bütçesi uygun olduğu zaman ve kendine uygun bir model bulduğunda giysi alışverişi yaptığı özel günlere yönelik ise giysi alışverişi yapmadığı sonucuna ulaşılmıştır. Öğrenciler giyim markalarından; kalıpların bedene uygun olmasını, model çeşitliliğinin fazla olmasını, ekonomik olmasını ve farklı model özelliklerine sahip koleksiyonlarının olmasını bekledikleri ortaya çıkmıştır. Ayrıca giysilerde dayanıklı malzeme ve materyaller kullanılmasına da kesinlikle önem verdikleri belirlenmiştir. Markaların kendilerine ait bilgilerini paylaşması ve ürünlerinin fonksiyonel özelliklerinin olması konusuna katıldıkları görülür. Öğrenciler markaların herkes tarafından satın alınamamasını ve üst düzey ekonomik gelire hitap etmesini istememektedir. Öğrencilerin markalara ait ürünlerin alınabilir olmasını beklemeleri giysi alışverişlerine ayırdıkları bütçeleri dikkate alındığında tutarlı bir sonuçtur. Öğrencilerin tüm giysi çeşitlerini ve aksesuarları aynı markadan temin edebilmeyi istememeleri dikkat çekicidir.

Markalar duygusal faktörlere ilişkin değerlendirildiğinde; öğrenciler üzerinde en fazla bağlılık yaratan markalar sırasıyla, yerli rahat giyim E markası, yüksek gelir düzeyine sahip müşterilere hitap eden yabancı $\mathrm{D}$ markası ve yerli hızlı moda A markasıdır. En yaratıcı bulunan markalar; yabancı hızlı moda öncüsü B markası, yerli spor giyim E markası ve yüksek gelir düzeyine hitap eden yerli $C$ markasıdır. Farklılıklara hitap eden markalar ise yerli spor giyim E markası ve yabancı hızlı moda B markası şeklinde sıralanmıştır. Öğrenciler yerli A markasını en geleneksel ve en hesaplı aile odaklı marka olarak nitelendirmiştir. İri ve İnal (2011) tarafından da A markası yeniden konumlandırılması inceleme konusu olmuştur. Araştırmacılara göre, yerli A markası ürünlerini piyasadaki aynı tür ve kalitedeki ürünlere oranla, daha ucuza mâl etmekte ve modaya uygun olarak üretilen ürünlerini müşterilerine daha ucuza satma başarısı göstermektedir. Markalar duygusal olarak öğrenciler üzerinde dikkate değer merak uyandırmamakla birlikte en fazla yabancı hızlı moda B markasının tüketiciler tarafından merak konusu olduğu söylenebilir. En dikkat çeken markalar ise sırasıyla; yüksek alım gücüne hitap eden yerli $C$ markası, yabancı spor giyim $\mathrm{F}$ ve yerli spor giyim $\mathrm{E}$ markası olarak ifade edilmiştir.

Marka kişiliği kapsamında yapılan değerlendirmede, öğrenciler tarafından en samimi (mütevazi, dürüst, sağlam) yerli A ve E markaları 
olmuştur. Yabancı spor giyim F markası ise en coşkulu (cesur, heyecanlı, kışkırtıcı, sıra dışı) bulunmuştur. Yabancı spor giyim F, Yerli spor giyim E, yüksek gelire sahip müşterilere hitap eden yabancı $D$ ve hızlı modaya hitap eden yabancı B markaları en fazla ustalık (güvenilir, zeki, başarılı) algısı hissettiren markalar olmuştur. Öğrenciler en seçkin (üst sınıf, cazip) olarak yabancı hızlı moda $B$ ve yüksek alım gücüne hitap eden yabancı $D$, üst düzey gelire hitap eden yerli $C$ markalarını ifade etmişlerdir.

Markalar fiziksel faktörleri açısından genel değerlendirildiğinde model çeşitliliği en fazla olan markalar yerli A ve yabancı B markaları olarak sıralanmıştır. Bu markaların model çeşitliliğin fazla olduğunun belirtilmesi hızlı modaya yönelik çalışmalarından kaynaklanmaktadır. Modelleri özgün ve orijinal bulunan markalar sırasıyla, yabancı spor giyim $\mathrm{F}$ markası, hızlı moda yabancı B markası, yerli spor giyim E markası ve yerli C markasıdır. Kalıplarının bedene en uygunluğu açısından bakıldığında A markası ön plana çıkmıştır. Kalıplar konusunda bu markanın ön plana çıkmasındaki neden yerli üretim yapmalarından kaynaklı olabilir. Modellerini aksesuarla desteklemeleri konusunda markaların aralarında dikkate değer farklar ortaya çıkmamıştır. A markası aynı zamanda her yaş grubuna uygun modeller bulunan marka olarak da belirtilmiştir. Markalar kumaşlarının doğaya uygunluğu açısından değerlendirildiğinde dikkate değer oranlar yer almamakla birlikte yerli C markası ön plana çıkar.

Duygusal, marka kişiliği, fiziksel faktörler olmak üzere üç ana kategori altında markalara yönelik öğrenci görüşlerinin incelendiği çalışmada tüm kriterlerden en fazla yerli spor E, yabancı spor F ve hızlı moda B markaları değerlendirilmiştir. Öğrenciler, duygusal faktörlerden en fazla yerli spor E ve hızlı moda yabancı B markalarını, marka kişiliği olarak en fazla yabancı spor F ve yerli spor E markaları için görüş bildirmişlerdir. Araştırmadan elde edilen sonuçlara göre; öğrencilerin bütçelerine uygun buldukları markalara ilişkin daha fazla faktör açısından değerlendirme yapabildikleri görülür. Katılımcıların satış fiyatlarını diğerlerine nispeten daha yüksek buldukları markaların duygusal veya marka kişiliği faktörleri hakkında fikir sahibi olmalarına karşın, fiziksel faktörlerine ilişkin görüş bildirmekten çekindikleri ortaya çıkmıştır. Duygusal ve marka kişiliği ile ilgili olan esaslar marka imajının getirisi olduğundan marka tanınırlığına bağlıdır. Fiziksel faktörlere ilişkin kriterler ise kullanım tecrübesine yöneliktir. Öğrenciler satın almadıkları ve kullanmadıkları bir 
markanın fiziksel faktörleri hakkında fikir sahibi olmayabilir. Bu çalışma moda alanında eğitim gören üniversite öğrencilerinin markaların duyusal, imaj ve fiziksel özelliklerine yönelik algılarını belirlemeye yönelik yapılmıştır. Öğrencilerin daha çok alıp kullanabildiği genç tüketicilere hitap eden markalara daha fazla görüş bildirdikleri, alıp kullanmadıkları markalarda bile marka imajına yönelik fikir sahibi oldukları ortaya çıkmıştır. Bu çalışmanın sonucu olarak pazarlama ilkeleri açısından marka imajı ve marka kişiliği oluşturmanın tüketici üzerinde belirleyici ve kalıcı bir etkisi olduğu açıkça görülmüştür. Markaların soyut olarak nitelendirilen imaj ve marka kişiliği özellikleri medya, internet ve iletişim araçlarını en etkili biçimde kullanan genç tüketici kitlesi tarafından net biçimde anlaşılmaktadır. Bu durumda markalar uzun vadede hedef kitlelerine vermek istediği mesajlarını stratejik olarak planlamalı ve aktarma konusunda dikkatli olmalıdır. 


\title{
EXTENDED ABSTRACT
}

\section{Fashion Design Students' Views on Clothing Brands: Giresun University Study Case *}

\author{
Tuğba Seferoğlu - Hatice Harmankaya \\ Giresun University-Selçuk University
}

Brand is a set of characteristics that form the individual's satisfaction gained from items bought. These are real or imaginary, rational or emotional, visible or invisible features that make up the brand. To distinguish the products or services produced by many companies, to provide information about the products or services and to creta an image appear as a symbol, desing, color, packaging, label and brand introducing products and services to bring in an identify. Therefore, it is inevitable to emphasize symbolic features in order to create a difference in products and attract the attention of consumers.

The aim of this study is to determine the perception status of the cloth brands characteristics by fashion design students. The sample of the study using descriptive research method consists of the students in Giresun University, Şebinkarahisar School of Applied Sciences, Fashion Design Department. The data were obtained with the developed questionnaire. The questionnaire consists of four main sections: demgraphic characteristics of the students, features that students care about clothes exchange, students' expectations from cloth brands and finally their opinions about cloth brands.

The questionnaire was applied to 152 people, 38 out of each grade and 138 of them were found suitable for analysis. In the survey, the fast-fashion domestic A brand, the fast-fashion foreign B brand, the domestic C brand appealing to the consumer group with high-level income, the foreign $\mathrm{D}$ brand with a high purchasing power, In terms of casual wear, the world-renowned domestic brand $\mathrm{E}$ and the pioneer in sportswear has been selected as a high foreign $\mathrm{F}$ brand. Place is given to the best known brands in the elections in general by consumers. Survey reliability was measured and Cronbach Alpha $(\alpha)$ was found to be $95.2 \%$. After the data 
collection process was completed in the research process, the answers given to the questionnaire were checked, missing or incorrect questionnaires were separated and the data were transferred to SPSS package program for statistical analysis on the correct questionnaires. The findings are given as percentage and number values in the tables.

The five - likert type scale was used in order to measure the characteristics participants care about clothes exchange and the participants' expectations from the cloth brands. In this research, university students' opinions on the brands covered by the research were determined by structuring 'Brand Features' under three variables including emotional factors, brand personality and physical factors. The results obtained from this research were given as percentage and number values in the tables. In addition, $\chi^{2}$ correlation analysis was used to measure the statistical relationship between charateitics university students pay attention in the fashion brands perceptions and their license levels. Furthermore, ANOVA analysis was performed in order to test whether there is a statistically significant difference between characteristics participants in the research group care about according to their license level on clothes exchange and their expectation from cloth brands. As a result of the study, it has been revealed that creating brand image and brand personality for the enterprises has a decisive effect on the consumer. It is determined that the brand's abstract features are clearly understood by the young consumer population.

According to the results of the research conducted in order to determine the opinions of the students in the Department of Fashion Design on the emotional, brand personality and physical factors of brands; It was found out that the parents of the students had high school graduates, and the students had 500 TL or more money in their hands, spent 50 to $100 \mathrm{TL}$ per month on clothing shopping. It is seen that most of the university students live with their families in Marmara and Black Sea regions. It was revealed that fashion design students exchanged clothes when they found the most appropriate budget and found a suitable model. It was concluded that students did not exchange clothes for special days. Expectations of students from clothing brands; the suitability of the clothing patterns to be suitable for the body, the diversity of the models, being economical and having collections with different model characteristics. 
Domestic sports $\mathrm{E}$, foreign sport $\mathrm{F}$ and fast fashion $\mathrm{B}$ brands were evaluated most of all the criteria in the study Students' opinions about brands were examined under three main categories: emotional, brand personality and physical factors. The students reported the most domestic sports $\mathrm{E}$ and fast fashion foreign $B$ brands from the emotional factors, and the most foreign sports $\mathrm{F}$ and domestic sports $\mathrm{E}$ brands as brand personality. According to the results of the study; It is seen that students can make evaluations in terms of more factors related to the brands they find appropriate for their budgets. It was found out that the participants had an idea about the emotional or brand personality factors of the brands they found their sales prices higher than others but they were reluctant to express their opinions on their physical factors.

The principles related to the emotional and brand personality are based on the brand recognition as it is the return of the brand image. Criteria related to physical factors are intended for use. Students may not have an idea about the physical factors of a brand that they do not buy or use. It has been found out that students have more opinions about brands that appeal to young consumers who can buy more and use them, and they have an idea about brand image even in brands they do not use. As a result of this study, it is clear that creating brand image and brand personality in terms of marketing principles has a decisive and lasting effect on the consumer. The brand's image characteristics and brand personality characteristics are clearly understood by the young consumer group who uses media, internet and communication tools in the most effective way. In this case, the brands should plan their messages strategically in the long term and should be careful about the transfer.

\section{Kaynakça / References}

Aaker, D. A. (2009). Marka değeri yönetimi. (E. Orfanl, Çev.). İstanbul: MediaCat Yayınları.

Ağaç, S. Sevinir, S. D. (2018). Marka yarar boyutlarına ilişkin bir ölçek sinaması: moda sektörü örneği. Pamukkale Üniversitesi Sosyal Bilimler Enstitüsü Dergisi, 30, 312-327. 
Aktuğlu, I. K. Temel, A. (2006). Tüketiciler markaları nasıl tercih ediyor? (Kamu sektörü çalışanlarının giysi markalarını tercihini etkileyen faktörlere yönelik bir araştırma). Selçuk Üniversitesi Sosyal Bilimler Enstitüsü Dergisi, 15, 35-57.

Atlı, S. M. (2001). Marka türleri ve korunması. Yayımlanmamış yüksek lisans tezi, Dokuz Eylül Üniversitesi, İzmir, Türkiye.

Aytuğ, S. ve Özgüven, N. (2011). Pazarlama yönetimi. İzmir: Detay Yayıncrlik.

Azizağaoğlu, A. ve Altunışık, R. (2011). Hazır giyim markalarının fonksiyonel ve sembolik özelliklerinin algılanan kalite ve marka bağlılığ1 üzerine etkileri. Tüketici Ve Tüketim Araştırmaları Dergisi, 2. 103. 30 Ekim 2017 tarihinde http: // betadergi. com/ ttad /yonetim / icerik / makaleler / 25-published.pdf adresinden erişildi.

Bağrışen, Y. Ö. (1999). Sanatsal yaratıcılı̆̆ın giyim tasarımında ve marka oluşumundaki yeri. Yayımlanmamış sanatta yeterlilik tezi, Marmara Üniversitesi, İstanbul, Türkiye.

Baudrillard, J. (2004). Tüketim toplumu. (F. Keskin ve N. Tutal, Çev.). İstanbul: Ayrıntı Yayınları.

Çeğindir, N. Y. Çakmak, Ş. (2018). Giysi örneğinde moda ürün geliştirme. Ankara: Gece Akademi.

Çetin, K. (2016). Kadın tüketicilerin giysi satın alma davranışları ve marka bağımlılığı. Ahi Evran Üniversitesi Sosyal Bilimler Enstitüsü Dergisi, 2, 28-31. 1 Mart 2019 tarihinde http://dergipark.gov.tr/download/article-file/264673 adresinden erişildi.

Denli, N. (2007). Giyim sektöründe marka imajı odaklı iletişim stratejileri. Yayımlanmamış Yüksek Lisans Tezi, Ankara Üniversitesi, Ankara, Türkiye.

Eray, F. (1999). Hazır giyim sanayinde marka-reklam ve tüketici ilişkileri. Mesleki eğitim dergisi, 2, 103. 3 Kasım 2017 tarihinde http://reklamajansim.blogspot.com/2008/08/hazir-giyim-sanayinde-markareklam-ve.html adresinden erişildi.

Erdem, Ş., Karsu, S., Memiş, E. ve Yıldız, O. (2010). Denim pazarında marka konumlandırmalarının karşılaştırılması. Marmara İktisadi Ve İdari Bilimler Dergisi, 1, 351-384. 
Iş1k, E. (2007). Hazır giyim ürünlerinde marka imajı yaratmanın önemi ve işletmeler açısından incelenmesi. Yayımlanmamış yüksek lisans tezi, Gazi Üniversitesi, Ankara.

İri, R. ve İnal, M. E. (2011). Bir hazır giyim markasının pazardaki değişiminin hikâyesi: 1c waikiki örneği. Süleyman Demirel Üniversitesi İktisadi Ve İdari Bilimler Dergisi, 1, 467. 29 Ocak 2018 tarihinde http://dergipark.gov.tr/download/article-file/194533 adresinden erişildi.

Kaptanoğlu, Ö. R. Kılıçarslan, M. ve Tosun, A. (2019). Marka ve marka farkındalığı. The journal of Social Science, 5. 248-256. 18 Mart 2019 tarihinde http://dergipark.gov.tr/tjsosci/issue/43451/520673 adresinden erişildi.

Karataş, A. ve Altunışık R. (2015). Yerli ve yabancı markalarının tüketici zihnindeki konumları ve algılanan müşteri değerlerinin karşılaştırılması. Kafkas Üniversitesi İktisadi ve İdari Bilimler Fakültesi Dergisi, 10, 138. 27 Nisan 2018 tarihinde https://www.kafkas.edu.tr/dosyalar/iibfdergi/file/10/8(1).pdf adresinden erişildi.

Kırdar, Y. (2005). Marka stratejilerinin oluşturulmasi: Coca-cola örneği. Review Of Social, Economic \& Business Studies, 4, 234. 30 Ekim 2017 tarihinde https: //docplayer.biz.tr/396626-Marka-stratejilerininolusturulmasi-coca-cola-ornegi.html adresinden erişildi.

Odabaşı, Y. (2006). Tüketim kültürü-yetinen toplumdan tüketen topluma. İstanbul: Sistem Yayıncilık.

Özçelik, D. G. Torlak, Ö. (2011). Marka kişiliği algısı ile etnosentrik eğilimler arasındaki ilişki: levıs ve mavi jeans üzerine bir uygulama. Ege Akademik Bakış Dergisi, 3, 363. 1 Mart 2019 tarihinde http://dergipark.gov.tr/download/article-file/558803 adresinden erişildi.

Özgüven, N. ve Karataş, E. (2010). Genç tüketicilerin marka kişiliği algılamalarının cinsiyete göre değerlendirilmesi: mcdonald's ve burger king. Süleyman Demirel Üniversitesi Sosyal Bilimler Enstitüsü Dergisi, 11, 143.

Sevil, B. (2006). Moda sektöründe küresel marka yaratılması: markalaşma çalışmaları üzerine bir uygulama. Yayımlanmamış Yüksek Lisans Tezi, Dokuz Eylül Üniversitesi, İzmir, Türkiye. 
Song, Y., Hur, W. M. ve Kim, M. (2012). Brand trust and affect in the luxury brand customer relationship. Social behavior and personality research, $2,332$.

Sönmez, E. (2010). Giyimde marka bağl1lığı ve marka duyarlılığı: gençler üzerine bir araştırma. Erciyes Sosyal Bilimler Enstitüsü Dergisi, 28, 68. 30 Ekim 2017 tarihinde http://sbedergi.erciyes.edu.tr/sayi_28/4.pdf adresinden erişildi.

$\mathrm{Su}, \mathrm{J}$. ve Xiao Tong, X. (2016). Brand personality, consumer satisfaction, and loyalty: a perspective from denim jeans brands. Family and Consumer Sciences Research Journal, 4, 427, 17 Mart 2019 tarihinde https://onlinelibrary.wiley.com/doi/10.1111/fcsr.12171 adresinden erişildi.

Yousaf, U., Zulfıqar R., Aslam M. ve Altaf, M. (2012). Studying brand loyalty in the cosmetics industry. Scientific Journal of Logistics, 4, 327. 30 Ekim 2017 tarihinde http://www.logforum.net/pdf/8_4_6_12.pdf 327-337 adresinden erişildi.

\section{Kaynakça Bilgisi / Citation Information}

Seferoğlu, T. ve Harmankaya, E. (2019). Moda tasarımı öğrencilerinin giyim markalarına yönelik görüşleri: Giresun üniversitesi örneği. OPUS-Uluslararası Toplum Araştırmaları Dergisi, 11(18), 157-179. DOI: 10.26466/opus.521104 